\title{
À ESPERA DO PAI
}

Nunca odiei tanto o pai. Eu o esperava na porta de casa. Ele descia a rua de pedregulhos. Havia pouco tempo deixáramos a roça. Agora, tínhamos de cavar um chão de concreto e asfalto. Trocamos a companhia de bois vagarosos pela insana voracidade de carros e ônibus. Aos poucos, nos acostumaríamos ao ruído da nova vida. Atrás da casa de madeira, construímos nosso estádio - um estropiado Maracanã ladeado por cedros e uma tímida valeta. Nossa rede, as ancas do paiol em cujas vísceras dormiam ratos pançudos. E as ripas para a construção das estufas na floricultura onde morávamos de favor. Éramos retirantes num mundo que nos amedrontava.

O pai carrega o pacote. E vem em minha direção. Eu o espero. A ansiedade pulsando nas vértebras do pescoço. Um nó prestes a estourar no urro do animal ancestral. Ele caminha devagar, como se ambicionasse congelar o tempo, paralisar o momento de entregar ao filho o pão que jamais saciaria a fome que arranhava as costelas delicadas. Te odiei tanto, pai, na tarde sem fim. A mãe ali por perto cuidando das azaleias, avencas e samambaiais. Eu já havia anunciado aos amigos. A minha espera era a espera deles. Éramos uma horda de gnus à beira de um rio seco, sem crocodilos. Correríamos em disparada ao nosso estádio de mentira. Seríamos, enfim, pequenos deuses capazes de milagres indecentes. Bastava o pai me estender as mãos grossas, calosas, herança de uma roça arcaica e indesejada. $\mathrm{O}$ pai estendeu-me as mãos. Sobre elas, o pacote. Um simulacro de Papai Noel, cujas vestes tornavam risível a triste silhueta. Toma, filho. Agarrei com todas as minhas forças de nove anos. Davi e Golias trocando carícias e gentilezas. Rasguei o papel esverdeado feito o esfomeado a estraçalhar o vestido da amante.

À minha volta, pares de olhos em febre. Enfim, abandonaríamos a bola de plástico emprestada. Teríamos nossa bola: grande, branca, de capotão. Do papel 


\section{P $\quad \mathrm{R} \quad \mathrm{O} \quad \mathrm{S} \quad \mathrm{A}$}

amassado, a desilusão. Uma bola pequena, de cor escura, de borracha, fincava espinhos na palma da minha mão. Gostou, filho? A pergunta do pai se perdeu no silêncio indestrutível. Quietos e resignados, rumamos ao nosso estádio. Eu carregava o ódio debaixo do braço.

A bola pequena e feia - borracha maldita - rapidamente se transformou. Inventamos a bola perfeita. Nosso silêncio virou algazarra. Os gnus ruidosos lambiam o rio caudaloso. Crocodilos não nos assustavam. Inventamos dribles para a bola que pulava uma imensidão. Nossos pés sofriam para dominá-la. Aos poucos, arrefecemos a sua fúria. Driblamos e a chutamos vida afora.

Dói menos odiar o pai quando se está feliz.

(Texto lido na Feira de Frankfurt, em 2013.)

Rogério Pereira nasceu em Galvão (SC), em 1973. É jornalista, editor e escritor. Em 2000, fundou em Curitiba o jornal Rascunho - uma das raras publicaçôes sobre literatura no Brasil. Desde janeiro de 2011, é diretor da Biblioteca Pública do Paraná. Tem contos publicados no Brasil, Alemanha, França, Peru e Finlândia. É autor do romance Na escuridão, amanhã (2013), finalista do Prêmio São Paulo de Literatura, menção honrosa no Prêmio Casa de Las Américas (Cuba) e traduzido na Colômbia. 